\title{
Leverage, Ukuran Perusahaan, Dan Fixed Asset Intensity Dan Pajak Penghasilan Dimoderasi Regulasi Insentif Pajak Revaluasi Aset
}

Hadi Purwanto ${ }^{1}$

${ }^{1}$ Universitas Pancasila, Jl. Srengseng Sawah, Jagakarsa, Jakarta Selatan, 12640

\section{INFO ARTIKEL}

JEL Classsification:

M41

G18

Keywords:

leverage , firm size,

fixed asset intensity, asset revaluation, income tax.

\section{ABSTRACT}

This study aims to investigate the influence of leverage, firm size and fixed asset intensity to Income Tax moderated by PMK 191/2015 in listed companies on the Indonesia Stock Exchange. This study uses quantitative data that have been published in the Indonesia Stock Exchange and tax revenue from DGT. The samples used in this study were 145, including 102 companies that met the study criteria, as this study using purposive sampling method in sample selection. Method of data analysis using technique of moderated regression analysis with Warp-pls. The result of the research shows that firm size has a significant effect directly to PPh on revaluation. Leverage and fixed asset intensity have no direct effect on income tax on revaluation. While the effect of leverage and fixed asset intensity on Income Tax of asset revaluation fully moderated (pure moderator) by PMK 191/2015. Otherwise , PMK 191/2015 play role as predictor moderator variable in relation of firm size's effect on Income Tax of asset revaluation.

\begin{abstract}
ABSTRAK
Penelitian ini bertujuan untuk meneliti pengaruh leverage, ukuran perusahaan dan fixed asset intensity terhadap $\mathrm{PPh}$ atas revaluasi aktiva tetap dengan dimoderasi PMK 191/2015 pada perusahaan yang terdaftar di Bursa Efek Indonesia. Penelitian ini menggunakan data kuantitatif yang telah dipublikasikan di Bursa Efek Indonesia dan data realiasi pajak Direktorat jenderal Pajak. Dimana sampel yang digunakan dalam penelitian ini sebanyak 145 yang terdiri dari 102 perusahan yang memenuhi kriteria penelitian, karena penelitian ini menggunakan metode purposive sampling dalam pemilihan sampel. Metode analisis data menggunakan teknik moderated regression analysis dengan Warp-pls. Hasil penelitian menunjukkan bahwa ukuran perusahaan berpengaruh signifikan secara langsung terhadap PPh atas revaluasi. Leverage dan fixed asset intensity tidak berpengaruh langsung terhadap PPh atas revaluasi. Sedangkan PMK 191/2015 terbukti memoderasi sempurna (pure moderasi) PPh atas Revaluasi. Sementara PMK 191/2015 berperan sebagai variabel prediktor (predictor moderator variable) dalam hubungan pengaruh ukuran perusahaan terhadap $\mathrm{PPh}$ atas revaluasi.
\end{abstract}




\section{Pendahuluan}

Pelaporan keuangan diatur sedemikian dengan tujuan menghasilkan laporan keuangan yang dapat menyajikan informasi andal dan reliable untuk pengambilan keputusan. Namun seiring dengan berjalannya waktu, akuntan menemukan banyak celah dalam pendekatanpendekatan pelaporan keuangan yang telah ada, untuk melakukan fraud (kecurangan). Hal ini merupakan salah satu sebab munculnya pengaturan akuntansi baru yang principal based yaitu IFRS (International Financial Reporting Standard).

Data pada perusahaan yang terdaftar di Bursa Efek Indonesia yang terdaftar tahun 2011, dapat disampaikan bahwa perusahaan cenderung memilih alternatif akuntansi yang menghindari nilai wajar (fair value), sedangkan nilai wajar atau nilai revaluasi kurang dipilih. Hal ini disebabkan, karena penggunaan model revaluasi menimbulkan masalah pajak yang signifikan (Saptono dan Suwardi: 2013).

Masalah pajak dapat muncul dalam penerapan Pernyataan Standar Akuntansi Keuangan (PSAK) 16 (Revisi 2011): Aktiva Tetap. PSAK ini harus diterapkan untuk periode tahunan yang dimulai pada atau setelah 1 Januari 2012. PSAK mengacu pada International Accounting Standard No. 16 (Revisi 2009): Aktiva Tetap. Ada dua model untuk pengukuran berikutnya: model biaya dan model revaluasi. Pada penerapan model badan tidak akan menemui masalah pajak sebagai peraturan pajak Indonesia menetapkan bahwa aktiva diukur berdasarkan biaya historis. Namun, ketika menerapkan model revaluasi, badan secara teratur memiliki untuk merevaluasi aktiva tetap sesuai dengan paragraf 31 PSAK 16 (Revisi 2011). ayat tersebut menetapkan sebagai berikut: "Setelah pengakuan sebagai aktiva, item aktiva tetap yang nilai wajarnya dapat diukur secara andal harus dilakukan pada nilai revaluasi, nilai wajar pada tanggal revaluasi dikurangi akumulasi penyusutan dan akumulasi rugi penurunan nilai berikutnya. Revaluasi harus dilakukan dengan keteraturan yang cukup untuk memastikan bahwa jumlah tercatat tidak berbeda secara material dari yang akan ditentukan dengan menggunakan nilai wajar pada akhir periode pelaporan"(IAI, 2011).

Model revaluasi, berdasarkan peraturan pajak, akan ada keuntungan dari revaluasi aktiva tetap. Pertanyaan selanjutnya adalah apakah atau tidak otoritas pajak dapat mengenakan pajak $10 \%$ atas keuntungan ketika entitas yang dicatat berlaku surat untuk mendapatkan persetujuan dari Direktorat Jenderal Pajak mengacu Peraturan Menteri Keuangan Nomor. 79/PMK.03/2008 dan Pasal 19 UndangUndang Pajak Penghasilan. Menurut aturan ini, entitas sebagai Wajib Pajak, perusahaan diijinkan untuk menerapkan revaluasi aktiva tetap untuk tujuan fiskal yang merupakan obyek Pajak Penghasilan. Aturan menetapkan bahwa Direktorat Jenderal Pajak memiliki kewajiban untuk merespon surat permohonan Wajib Pajak, baik menyetujui atau menolak permohonan revaluasi. Pajak Penghasilan Final sebesar 10\% terutang atas surplus revaluasi yang merupakan selisih antara nila aktiva hasil revaluasi dengan nilai buku aktiva. Secara ketentuan Wajib Pajak yang akan melakukan revaluasi aktiva tetap harus mengajukan permohonan dan menunggu persetujuan dari Direktorat Jenderal Pajak. Sedangkan timbul biaya untuk penilaian aktiva dilakukan oleh seorang profesional di bidangnya, yaitu biaya penilaian aktiva oleh apraisal.

Pengambilan keputusan korporasi dalam memilih melakukan revaluasi atau tidak sangat di pengaruhi interaksi antar motive, pengaruh, impilkasi bisnis, dan hasil dari Revaluasi Aktiva Tetap (Zakaria, 2014). Melalui penelitian tersebut telah dikembangkan suatu model konseptual pengambilan keputusan bagi perusahaan dalam melakukan revaluasi aktiva tetap. Banyak motivasi perusahaan melakukan revaluasi aktiva tetap, seperti: untuk meningkatkan persepsi kesehatan keuangan kepada kreditor dan para pemegang saham dan juga meningkatkan kemampuan untuk meminjam (Pierra: 2007). 
Sedangkan bagi perusahaan, revaluasi dapat dijadikan sebagai sarana perencanaan perpajakan yang bertujuan untuk menghemat pembayaran pajak.

Bagi DJP, revaluasi akan berdampak kepada penerimaan Pajak Penghasilan. Surplus dari selisih nilai revaluasi dan nilai buku aktiva dikenakan Pajak Penghasilan Final 10\%. Dari data DJP, 3 (tiga) tahun sebelum dikeluarkannya PMK 191/2015 realisasi penerimaan pajak revaluasi aktiva tetap dan peminatnya sangatlah minim. Pada tahun 2015 terjadi kenaikan sangat tinggi baik jumlah pemohon maupun realisasi penerimaan Pajak Penghasilan atas Revaluasi aktiva tetap. Kenaikan tersebut terkonsentrasi di 3 (tiga) bulan terakhir tahun 2015. Sebagaimana diketahui pada bulan-bulan tersebut berlaku Peraturan Menteri Keuangan Nomor: 191/ PMK.03/2015 yang memberikan insentif fiskal bagi pengusaha yang akan melakukan revaluasi aktiva tetap untuk tujuan perpajakan berupa pemotongan tarif $\mathrm{PPh}$ atas revaluasi aktiva tetap. Bagi Wajib Pajak yang melakukan revaluasi terdapat kewajiban pajak, berupa Pajak Penghasilan Final sebesar 10\%. Dengan terbitnya PMK 191 Tahun 2015 yang memangkas tarif PPh Final Revaluasi Akiva Tetap dari 10\% menjadi $3 \%, 4 \%$ dan $6 \%$ diharapkan menjadi daya tarik bagi Wajib Pajak untuk melakukan revaluasi aktiva tetap. Bagi Pemerintah dengan revaluasi aktiva tetap ini diharapkan dapat meningkatkan penerimaan Pajak Penghasilan akibat revaluasi.

Kebijakan tax cut secara teoritis dalam jangka panjang tidak akan menurunkan penerimaan negara secara aggregate, bahkan sebaliknya akan meningkatkan penerimaaan negara dari jenis-jenis pajak lainnya. PMK 191 Tahun 2015 adalah insentif PPh pertama bagi pelaku bisnis yang akan melakukan revaluasi aktiva tetap sejak perubahan Undang Undang $\mathrm{PPh}$ terakhir tahun 2007. Penerbitan insentif pajak diskon tarif atas revaluasi aktiva tetap yaitu PMK 191 Tahun 2015 dapat mendorong motivasi Wajib Pajak merevaluasi aktiva tetapnya. Dan penurunan tarif ini dapat mendorong Wajib
Pajak merevaluasi aktiva tetapnya dibandingkan dengan tarif sesuai ketentuan sebelumnya.

Menarik untuk diteliti adalah Pajak yang ditimbulkan atas pengajuan permohonan Revaluasi Aktiva Tetap, dan faktor-faktor yang mempengaruhi perusahaan dalam mengambil keputusan terkait revaluasi aktiva tetap. Katuuk, Yolanda C (2013) meneliti impilkasi revaluasi aktva tetap berupa kenaikan PPh Final revaluasi (10\% dari surplus aktiva), kenaikan nilai pasar wajar aktiva, kenaikan biaya amortisasi, dan penghematan pajak (tax saving) terutama untuk revaluasi aktiva yang dapat disusutkan (depreciable asset).

Terdapat beberapa penelitian seperti (Listiyani, Yani ; 2015) menemukan leverage, dan intensitas aset tidak lancar memiliki pengaruh negatif signifikan terhadap revaluasi, sedangkan perubahan kas operasi dan ukuran perusahaan memiliki pengaruh positif tidak signifikan terhadap revaluasi. Cut Anisa Laatifa dan Musfiadi Harini (2016), meneliti tentang pengaruh Negoisasi Debt Contract, Political Cost, Fixed Asset Intensity, dan Market to Book Value terhadap Revaluasi Aset Tetap. Studi di Perusahaan Manufaktur yang Terdaftar di Bursa Efek Indonesia Tahun 2010-2014. Dari penelitian ditemukan debt contracts berpengaruh negatif terhadap revaluasi aset tetap, political cost tidak berpengaruh terhadap revaluasi aset tetap, fixed asset intensity dan market to book ratio berpengaruh positif terhadap revaluasi.

Tay (2009), menemukan firm size dan fixed asset intensity berpengaruh terhadap keputusan melakukan revaluasi aset tetap. Sementara leverage, liquidity, dan market to book ratio berpengaruh signifikan negatif terhadap perusahaan untuk melakukan revaluasi aktiva tetap. Yuliasta et. Al (2015), menemukan kegagalan pembuktikan bahwa leverage, arus kas operasi, dan ukuran perusahaan, Fixed Asset Intensity dapat mempengaruhi perusahaan untuk melakukan revaluasi. Hal ini sejalan dengan penelitian yang dilakukan Yustia et. al. (2015) dengan judul Pengaruh Leverage, Arus Kas 
Operasi, Ukuran Perusahaan, dan Fixed Asset Intensity terhadap Revaluasi Aktiva Tetap. Penelitian tersebut tidak berhasil membuktikan fakta leverage, penurunan arus kas operasi, ukuran perusahaan, dan fixed asset intensity mempengaruhi manajer untuk melakukan revaluasi aktiva tetap.

Peneliti juga menambahkan kebijakan PMK 191/2015 sebagai variabel permoderasi. Sebagaimana dapat dilihat pada table 1.2, penerimaan $\mathrm{PPh}$ Final atas revaluasi aktiva tetap di tahun 2015 yaitu tahun berlakunya PMK 191/2015 melonjak tajam dibandingkan 3 (tiga) tahun sebelumnya. Surlpus revaluasi yang diperoleh akibat memanfaatkan kebijakan PMK 191/2015 direspon positif oleh pelaku usaha dengan melakukan pembayaran $\mathrm{PPh}$ Final dalam rangka mengajukan permohonan revaluasi aktiva tetap untuk tujuan perpajakan. Berdasarkan latar belakang diatas maka penulis tertarik untuk meneliti "Pengaruh Leverage, Ukuran Perusahaan dan Fixed Asset Itensity Tetap terhadap Pajak Penghasilan yang dimoderasi PMK Nomor 191 Tahun 2015”.

\section{Telaah Teori dan Pengembangan Hipotesis}

Pengaruh Leverage Terhadap Pajak Penghahasilan atas Revaluasi Aktiva Tetap

Perusahaan dengan utang tinggi akan lebih mungkin untuk merevaluasi aset tetap mereka, sehingga tunduk pada perjanjian hutang mereka dan juga bisa meminjam lebih jauh dengan istilah yang lebih baik (Whittred dan Chan, 1992). Revaluasi aset tetap dapat mempengaruhi kekuatan perusahaan dalam negosiasi kontrak utang dengan pemberi pinjaman (Seng dan Su, 2010). Revaluasi aset memiliki keuntungan menurunkan leverage, menurunkan probabilitas kegagalan perjanjian kontrak utang, dan memberikan sinyal yang baik (Cotter, 1999), mempengaruhi angka-angka akuntansi sehingga keputusan manajemen untuk merevaluasi aset mengubah keuangan perusahaan, yaitu mengubah rasio debt to total tangible asset.

Peneliti-peneliti sebelumnya di beberapa negara menemukan hubungan antara tindakan revaluasi dengan leverage, misalnya di Inggris (Lin dan Peasnell, 2000a, 2000b; Iatridis, 2011), di Iran (Tabari dan Adi, 2014). Perusahaan akan melakukan revaluasi asset jika tingkat leverage perusahaan tinggi, misalnya di Australia (Brown et al, 1992); dan di Swiss (Piera, 2007); Perusahaan dengan growing debt akan merevaluasi aset (Barac dan Sodan, 2011). Adanya laporan posisi keuangan yang kuat, akan meyakinkan pemberi pinjaman bahwa perusahaan dapat membayar utang. Revaluasi aset akan memungkinkan perusahaan menghindari kemungkinan denda atau biaya pelunasan terkait dengan pelanggaran perjanjian hutang. Atas pilihan perusahaan melakukan Revaluasi Aktiva Tetap akan timbul PPh Final atas Revaluasi.

Hipotesis yang diuji adalah:

H1. Perusahaan dengan tingkat leverage yang tinggi akan akan memilih melakukan Revaluasi Aktiva Tetap dan membayar Pajak Penghasilan atas Revaluasi Aktiva Tetap.

\section{Pengaruh Ukuran Perusahaan Terhadap Pajak Penghasilan atas Revaluasi Aktiva Tetap}

Biaya politik sering dihubungkan dengan ukuran perusahaan (Watts dan Zimmerman, 1986). Penelitian-penelitian sebelumnya menggunakan ukuran perusahaan sebagai proksi political factor (Lin dan Peasnell, 2000a). Menurut Seng dan Su (2010) ukuran perusahaan merupakan faktor penting dalam keputusan perusahaan untuk merevaluasi aset. Perusahaan besar akan menggunakan prosedur penurunan pendapatan (income reducing) dan mengurangi kemungkinan rugi akibat regulasi (Brown et al. 1992). Karena ingin menurunkan tekanan politik pemerintah atau serikat buruh, perusahaan besar akan menghindari pelaporan laba yang tinggi. Revaluasi aktiva tetap merupakan cara efektif untuk menurunkan pelaporan laba melalui peningkatan biaya depresiasi sebagai akibat peningkatan aset revaluasi (Seng dan $\mathrm{Su}, 2010$ ). 
Christoffersen dkk. (2006) telah menemukan bahwa ada hubungan positif antara ukuran perusahaan dan revaluasi aset tetap. Penelitian di luar negeri menemukan bahwa perusahaan besar akan merevaluasi aset tetap (Brown et al., 1992; Tay, 2009; Seng dan Su, 2010; Iatridis dan Kiligiotis, 2012). Revaluasi Aktiva Tetap akan menimbulkan munculnya PPh Final atas Revaluasi.

Hipotesis yang diuji adalah:

H2. Perusahaan dengan ukuran lebih besar akan memilih melakukan revaluasi aktiva tetap dan membayar Pajak Penghasilan atas Revaluasi Aktiva Tetap.

\section{Pengaruh Fixed Asset Intensity Terhadap Pajak Penghasilan atas Revaluasi Aktiva Tetap}

Fixed asset intensity (intensitas aset tetap) merupakan proporsi aset perusahaan yang terdiri dari aset tetap (Tay, 2009). Fixed asset intensity merupakan salah satu faktor yang diuji terkait dengan dalam asimetri informasi (Seng dan $\mathrm{Su}$, 2010). Pada keadaan asimetri informasi, maka satu pihak lebih memilik informasi atas transaksi dibandingkan pihak lainnya. Lin dan Peasnel (2000b) menemukan hubungan yang positif antara keputusan untuk melakukan revaluasi dengan intensitas asset tetap. Tay (2009) menemukan pengaruh fixed asset intensity terhadap revaluasi aset. Revaluasi aset tetap memungkinkan perusahaan untuk meningkatkan kredibilitas dan juga untuk menarik investor, dengan nilai aset yang lebih tinggi setelah revaluasi (Cotter and Zimmer, 1995; Cotter, 1999; Lin and Peasnell, 2000; Jaggi and Tsui, 2001). Perusahaan dengan intensitas asset lebih tinggi cenderung akan melakukan revaluasi aktiva tetap dengan membayar PPh Final atas Revaluasi Aktiva Tetap.

Hipotesis yang diuji adalah:

H3. Perusahaan intensitas asset tetap yang lebih tinggi akan memilih melakukan Revaluasi Aktiva Tetap dan membayar Pajak Penghasilan atas Revaluasi Aktiva Tetap.
Pengaruh Leverage Terhadap Pajak Penghasilan atas Revaluasi Aktiva Tetap dengan dimoderasi PMK 191/2015

PMK 191/2015, melalui surplus revaluasi akan mendorong motivasi perusahaan dengan leverage tinggi untuk melakukan revaluasi aktiva tetap. Revaluasi Aktiva Tetap akan menimbulkan munculnya penerimaan PPh Final atas Revaluasi.

Hipotesis yang diuji adalah:

H4. Perusahaan leverage tinggi akan memilih melakukan Revaluasi Aktiva Tetap dan membayar Pajak Penghasilan atas Revaluasi Aktiva Tetap dengan dimoderasi kebijakan PMK 191/2015.

\section{Pengaruh Ukuran Perusahaan Terhadap Pajak Penghasilan atas Revaluasi Aktiva Tetap dengan dimoderasi PMK 191/2015}

PMK 191/2015, melalui surplus revaluasi akan mendorong motivasi perusahaan dengan ukuran perusahaan besar untuk melakukan revaluasi aktiva tetap. Revaluasi Aktiva Tetap akan menimbulkan munculnya penerimaan $\mathrm{PPh}$ Final atas Revaluasi.

Hipotesis yang diuji adalah:

H5. Perusahaan ukuran perusahaan besar akan memilih melakukan Revaluasi Aktiva Tetap dan membayar Pajak Penghasilan atas Revaluasi Aktiva Tetap dengan dimoderasi kebijakan PMK 191/2015.

\section{Pengaruh Fixed Asset Intensity Terhadap Pajak Penghasilan atas Revaluasi Aktiva Tetap dengan dimoderasi PMK 191/2015}

PMK 191/2015, melalui surplus revaluasi akan mendorong motivasi perusahaan dengan fixed asset intensity (intensitas aktiva tetap) tinggi untuk melakukan revaluasi aktiva tetap. Revaluasi Aktiva Tetap akan menimbulkan munculnya penerimaan PPh Final atas Revaluasi. Hipotesis yang diuji adalah:

H6. Perusahaan dengan fixed asset intensity (intensitas aktiva tetap) yang lebih tinggi akan memilih melakukan Revaluasi Aktiva 
Tetap dan membayar Pajak Penghasilan atas Revaluasi Aktiva Tetap dengan dimoderasi kebijakan PMK 191/2015.

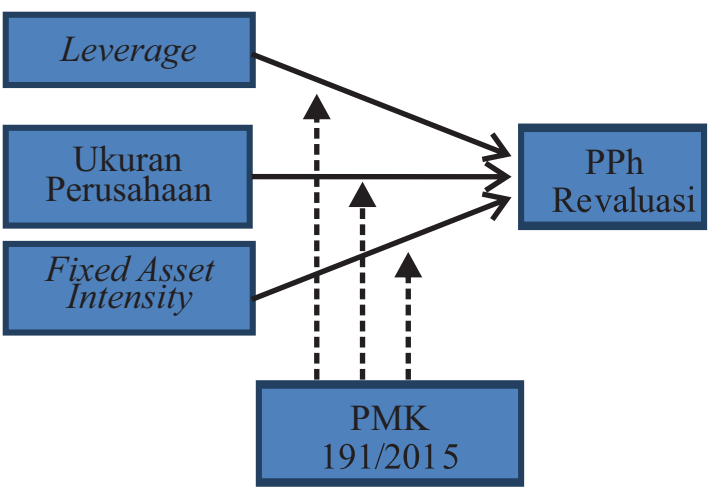

\section{Gambar 1. Skema Kerangka Pemikiran}

\section{Metode Penelitian}

Penelitian ini akan menguji pengaruh variabel independen, yaitu: leverage, ukuran perusahaan, dan fixed asset intensity terhadap variabel dependen penerimaan $\mathrm{PPh}$ atas Revaluasi Aktiva Tetap dengan variabel moderating kenaikan nilai perusahaan akibat Revaluasi, yaitu Surplus Revaluasi. Populasi dalam penelitian ini adalah seluruh perusahaan yang terdaftar yang terdaftar di Bursa Efek Indonesia sebelum diterbitkannya PMK 191/2015, yaitu per 19 Oktober 2015. Penelitian ini membatasi populasi dengan menggunakan teknik purposive sampling yaitu perusahaan yang melakukan revaluasi selama periode PMK 191/2015 dan melakukan publikasi Laporan
Keuangan tahun 2015 dan 2016 di Bursa Efek Indonesia.

Berdasarkan perumusan masalah, tujuan penelitian, dan metodologi penelitian, metode analisis yang digunakan dalam penelitian ini adalah analisis deskriptif kuantitatif. Selanjutnya menggunakan Uji Model Struktural dengan WARP - PLS. Penggunaan alat uji ini dilakukan karena data yang diolah tidak normal. Oleh karena itu digunakan pengujian dengan alat uji WARP -PLS.

\section{Hasil Penelitian Dan Pembahasan}

\section{Analisa Deskriptif}

Sebelum dilakukan pengujian hipotesis pertama sekali dilakukan analisis deskriptif untuk memberikan gambaran umum mengenai data penelitian. Statistik deskriptif memberikan gambaran atau deskriptif suatu data yang dilihat dari nilai rat-rata (mean), maksimum, minimum, median, dan standar deviasi. Analisa ini dimaksudkan untuk memberikan gambaran mengenai distribusi dan prilaku data sampel tersebut.

Dari 555 perusahaan yang terdaftar di Bursa Efek Indonesia tahun 2015, diperoleh sampel akhir penelitian ini terdiri atas 145 revaluasi yang diajukan oleh 102 perusahaan. Berikut di bawah ini adalah data revaluasi yang dilakukan oleh perusahaan yang terdaftar di Brusa Efek Indonesia selama berlaku PMK 191/2015 persektor kegiatan usaha:

Tabel 1. Statistik Deskriptif Populasi Penelitian

\begin{tabular}{|l|c|r|}
\hline \multicolumn{1}{|c|}{ Sektor Kegiatan Usaha } & $\begin{array}{c}\text { Permohonan } \\
\text { Revaluasi }\end{array}$ & \multicolumn{1}{c|}{$\begin{array}{c}\text { PPh atas } \\
\text { Revaluasi }\end{array}$} \\
\hline Aneka industri & 11 & $142,293,715,499$ \\
\hline Industri barang konsumsi & 16 & $41,892,748,348$ \\
\hline Industri dasar dan kimia & 30 & $906,080,667,559$ \\
\hline Infrastruktur, utilitas dan transportasi & 11 & $1,093,029,552,841$ \\
\hline Keuangan & 51 & $2,329,764,884,207$ \\
\hline Perdagangan jasa dan investasi & 13 & $130,947,927,312$ \\
\hline Pertanian & 5 & $14,024,255,250$ \\
\hline Properti, real estate dan konstruksi bangunan & 11 & $79,567,336,255$ \\
\hline Grand Total & $\mathbf{1 4 8}$ & $\mathbf{4 , 7 3 7 , 6 0 1 , 0 8 7 , 2 7 1}$ \\
\hline
\end{tabular}

Sumber: Data diolah 
Dari tabel 1 diperoleh gambaran bahwa perusahaan yang berminat dengan PMK 191/2015 adalah perusahaan sektor keuangan, yaitu sebanyak 51 perusahaan dengan $\mathrm{PPh}$ yang dibayar sebanyak 2,3 triliun, diikuti sektor industri dasar kimia sebanyak 30 perusahaan dengan nilai PPh yang dibayar sebesar Rp 906 miliar.. Sedangkan perusahaan di sektor pertanian memiliki minat yang rendah terhadap revaluasi aktiva tetap, yaitu sebanyak 5 perusahaan dengan setoran PPh sebesar 14 miliar.
Dari 148 revaluasi aktiva tetap yang dilakukan oleh 108 perusahaan yang terdaftar di Bursa Efek Indonesia (BEI), terdapat 3 revaluasi yang datanya tidak lengkap. Ketidaklengkapan data tersebut disebabkan karena informasi Laporan Keuangan yang dijadikan variabel tidak tersedia dan/ atau pembukuan menggunakan mata uang selain Rupiah. Sehingga data yang dijadikan sampel adalah 145 revaluasi oleh 102 perusahaan.

Data yang diperoleh sampel penelitian dapat diuraikan seperti pada tabel 2 di bawah ini:

Tabel 2. Hasil Pengujian Statistik Deskriptif

\begin{tabular}{|l|r|r|r|r|r|}
\hline & \multicolumn{1}{|c|}{ Min } & \multicolumn{1}{c|}{ Max } & \multicolumn{1}{c|}{ Mean } & \multicolumn{1}{c|}{ Median } & St Deviation \\
\hline Lev & 0,059 & 0,911 & 0,582 & 0,62522 & 0,239955 \\
\hline Size & 10,043 & 20,761 & 15,099 & 14,98992 & 2,215896 \\
\hline Intensty & 0,001 & 0,868 & 0,24784 & 0,17440 & 0,238092 \\
\hline M Rev & 0,990 & 7,400 & 4,998448 & 4,98000 & 1,111648 \\
\hline PPh & $-0,410$ & 5,880 & 3,53055 & 3,53055 & 1,091534 \\
\hline
\end{tabular}

Sumber : Data diolah

Tabel 2 menunjukan data 3 (tiga) veriabel bebas dan 1 (satu) variabel moderasi dalam penelitian dengan jumlah sampel secara keseluruhan sebanyak 145 sampel. Variabel Leverage (Lev) memiliki nilai rata-rata (mean) 0,582 , nilai maksimal 0,911 , nilai minimum 0,059 , nilai median 0,62522 dan standar deviasi 0,239955. Variabel Ukuran Perusahaan (Size) memiliki nilai rata-rata (mean) 15,099, nilai maksimal 20,761, nilai minimum 10,043 , nilai median 14,98992 dan standar deviasi 2,215896. Variabel Fixed Asset Intensity (Intensty) memiliki nilai rata-rata (mean) 0,24784 , nilai maksimal 0,868 , nilai minimum 0,001 , nilai median 0,17440 dan standar deviasi 0,238092. Variabel Moderasi, yaitu Surplus Revaluasi (M Rev) memiliki nilai rata-rata (mean) 4,998448, nilai maksimal 7,400 , nilai minimum 0,990 , nilai median 4,98000 dan standar deviasi 1,111648. Adapun variabel dependen berupa PPh memiliki nilai rata-rata (mean) 3,53055, nilai maksimal 5,880 , nilai minimum $-0,410$, nilai median 3,53055 dan standar deviasi 1,091534.

\section{Hasil Pengujian Hipotesis dan Pembahasan WARP - PLS}

Penelitian ini dibantu dengan menggunakan bantuan software Warp-PLS 6.0. Berikut hasil pengujian menggunakan software Warp-PLS 6.0. Hasil Pengujian Structural Model.

Pengujian structural model dilakukan dengan melihat koefisien determinasi $\left(\mathrm{R}^{2}\right)$ dan nilai koefisien jalur ( $\beta$ ).

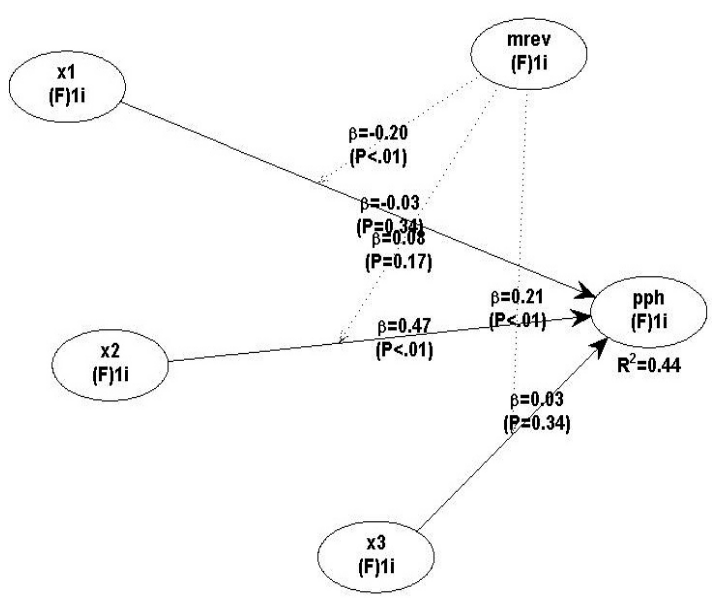

Gambar 2. Model Struktur Path Relation 


\section{Pengaruh Leverage Terhadap Pajak Penghasilan atas Revaluasi Aktiva Tetap}

Berdasarkan hasil penelitian, variabel leverage terbukti tidak berpengaruh terhadap Pajak Penghasilan atas Revaluasi Aktiva Tetap. Sedangkan koefisen jalur yang negatif membuktikan bahwa pengaruh leverage adalah negatif terhadap PPh atas Revaluasi aktiva tetap. Perusahaan dengan leverage tinggi memandang bahwa PPh atas revaluasi aktiva tetap sebagai beban ketimbang manfaat yang diperoleh setelah mengikuti revaluasi. Perusahaan dalam kondisi leverage tinggi lebih fokus menemukan cara bagaimana menghasilkan tambahan riil income untuk mengembalikan pinjaman kepada kreditor daripada memperoleh income berupa "Surplus Revaluasi" di mana tidak ada uang riil yang masuk ke perusahaan.

Di sisi lain bahwa revaluasi aktiva tetap banyak dilakukan perusahaan tanpa ada pembatasan. Perusahaan melakukan revaluasi dimaksudkan agar Laporan Keuangan semakin menarik. Sekarang ini, masih menjadi pertanyaan apakah leverage menjadi satusatunya kriteria pemberian tambahan hutang dan menentukan kemampuan perusahaan untu mengajukan pinjaman (borrowing capasity). Padahal kemampuan perusahaan untu mengajukan pinjaman (borrowing capasity) sangat bergantung assesment kreditur terhadap kemampuan debitur untuk membayar hutang. PPh yang dibayar atas Revaluasi aktiva tetap untuk dalam rangka tidak secara otomatis meningkatkan leverage perusahaan, karena kreditur lebih mempertimbangkan hal yang lebih penting dari pemberian hutang yaitu kemampuan perusahaan membayar hutang.

Hasil ini sejalan dengan penelitian Yulistia, dkk (2015) yang tidak menemukan pengaruh leverage terhadap revaluasi aktiva tetap. Penelitian lainnya yang hampir sama adalah penelitan Listiyani (2015) dan Latifa (2015), Seng dan Su (2010), dan Jaggi dan Tsui (2001). Penelitian-penelitian tersebut tidak menemukan perngaruh leverage terhadap keputusan atau
PPh yang muncul atas revaluasi aktiva tetap. Sedangkan penelitian ini faktor dependen yang diuji adalah PPh atas Revaluasi aktiva tetap, bukan keputusan manajemen apakah akan melakukan revaluasi aktiva tetap atau tidak. Penelitian yang dilakukan Tabari dan Adi (2014) juga menemukan hubungan antara tindakan revaluasi dengan leverage. Sedangkan hasil penelitian sebelumnya yang tidak sama adalah Piera (2007), Andison (2015) dan Natalius (2015). Penelitian mereka menemukan bahwa variabel leverage memiliki pengaruh positif terhadap keputusan revaluasi aktiva tetap.

\section{Pengaruh Ukuran Perusahaan Terhadap Pajak Penghasilan atas Revaluasi Aktiva Tetap}

Hasil penelitian menunjukan variabel ukuran perusahaan terbukti berpengaruh terhadap Pajak Penghasilan atas Revaluasi Aktiva Tetap. Perusahaan dengan ukuran besar cenderung bersikap konservatis terhadap profitabilitas untuk mengurangi biaya politik (political cost). Biaya politik mencakup semua biaya yang harus ditanggung perusahaan terkait tindakan-tindakan politis seperti pajak, regulasi, subsidi pemerintah, dan tuntutan buruh. Poltical cost yang ditanggung perusahaan besar lebih besar dibandingkan perusahaan kecil.

Perusahaan dengan ukuran besar cenderung manajemen laba untuk mengurangi political cost. Salah satunya usaha dengan mengurangi biaya PPh Badan yang terutang tiap tahun. PPh Badan dikenakan atas penghasilan setelah dikurangi seluruh biaya perusahaan termasuk penyusutan. Dengan mengeluarkan pengorbanan, berupa biaya PPh Final yang harus dikeluarkan apabila keputusan revaluasi aktiva tetap dilakukan, perusahaan dapat mengurangi beban PPh Badan yang harus dibayar melalui penambahan beban penyusutan atas aktiva yang direvaluasi.

Hasil sejalan dengan penelitian Ink Tay (2009), Seng dan Su (2010), Yulistia dkk. (2015) yang menemukan pengaruh ukuran perusahaan terhadap revaluasi aktiva tetap. Sedangan 
penelitian Tunggul Natalius (2015) menemukan pengaruh negatif ukuran perusahaan terhadap revaluasi aktiva tetap. Hasil penelitan terdahulu yang tidak sama adalah penelitian Seng dan $\mathrm{Su}$ (2010), yang menemukan ukuran perusahaan tidak berpengaruh terhadap revaluasi aktiva tetap.

\section{Pengaruh Fixed Asset Intensity Terhadap Pajak Penghasilan atas Revaluasi Aktiva Tetap}

Hasil penelitian menunjukan variabel fixed asset intensity terbukti tidak berpengaruh terhadap Pajak Penghasilan atas Revaluasi Aktiva Tetap. Fixed asset intensity merupakan rasio antara aktiva tetap dengan total aktiva. Dalam rasio/ intensitas aktiva tetap tinggi dapat dihasilkan oleh jumlah aktva tetap yang relatif kecil ataupun dan total aktiva relatif kecil pula. Dalam kondisi demikian, perusahaan tidak akan mempertimbangkan untuk melakukan revaluasi aktiva tetap, karena pertimbangan benefit dengan cost yang dibayar berupa $\mathrm{PPh}$ atas revaluasi aktiva tetap.

Hasil ini sama dengan penelitian Seng dan $\mathrm{Su}$ (2010) menemukan bahwa bahwa fixed asset intensity tidak memiliki pengaruh signifikan terhadap revaluasi aktiva tetap dengan menggunakan model regresi logistik. Natalius dkk (2015) dan Tay (2009) juga menemukan hasil yang sama bahwa fixed asset intensity tidak berpengaruh terhadap revaluasi aktiva tetap. Penelitian terdahulu yang tidak sama adalah penelitian Tay (2009), yang menemukan bahwa fixed asset intensity berpengaruh terhadap keputusan revaluasi aktiva tetap. Sedangkan Tabari dan Adi (2014) dalam penelitiannya mengemukakan bahwa perubahan aktiva tetap (CFA) memiliki pengaruh signifikan terhadap revaluasi. Adapun Iatridis (2012) menemukan bahwa perusahaan dengan fixed asset intensity rendah cenderung melakukan revaluasi aktiva tetap.

\section{Pengaruh Leverage Terhadap Pajak Penghahasilan atas Revaluasi Aktiva Tetap dengan dimoderasi PMK 191/2015}

Berdasarkan hasil penelitian, variabel leverage yang dimoderasi oleh PMK 191/2015 mempunyai tingkat pengaruh signifikansi lebih kecil dari tingkat signifikansi $(\alpha=0,1)<0,001$, ini berarti leverage yang dimoderasi oleh PMK 191/2015 melalui Surplus Revaluasi berpengaruh signifikan dan negatif terhadap Pajak Penghasilan atas Revaluasi Aktiva Tetap.

Para kreditor semakin menyadari bahwa revaluasi aktiva tetap semakin tren bagi perusahaan sebagai alat untuk meningkatkan kolateral dalam pengajuan pinjaman. Efek negatif yang muncul adalah kurangnya kredibilitas calon debitur yang mengajukan pinjaman setelah revaluasi aktiva tetap. Sehingga kreditor dapat menentukan pertimbangan tambahan untuk debitur yang mengajukan pinjaman revaluasi aktiva tetap. untuk para calon debitur yang mengajukan pinjaman setelah revaluasi aktiva tetap.

\section{Pengaruh Ukuran Perusahaan Terhadap Pajak Penghahasilan atas Revaluasi Aktiva Tetap dengan dimoderasi PMK 191/2015}

Berdasarkan hasil penelitian, variabel ukuran perusahaan yang dimoderasi oleh PMK 191/2015 (Size atau x2 _ M Rev) mempunyai nilai signifikan yang lebih besar dari tingkat signifikansi $(\alpha=0,1)$, ini berarti ukuran perusahaan yang dimoderasi oleh PMK 191/2015 tidak berpengaruh terhadap Pajak Penghasilan atas Revaluasi Aktiva Tetap.

Untuk perusahaan dengan ukuran besar, keputusan untuk revaluasi atau tidak terhadap aktiva tetap yang dimiliki tidak dipengaruhi oleh adanya insentif dari Pemerintah (PMK 191/2015). Keputusan melakukan revaluasi aktiva tetap lebih didasarkan apakah perusahaan membutuhkan aksi revaluasi atau tidak bagi perusahaan. Dan besar kecilnya PPh yang harus dibayar atas revaluasi tidak berpengaruh terhadap perusahaan dengan ukuran besar. 
Sehingga diskon tarif PPh Revaluasi tidak begitu mempengaruhi perusahaan besar.

\section{Pengaruh Fixed Asset Intensity Terhadap Pajak Penghahasilan atas Revaluasi Aktiva Tetap dengan dimoderasi PMK 191/2015}

Berdasarkan hasil penelitian, variabel fixed asset intensity yang dimoderasi oleh PMK 191/2015 (Intensty atau x3_ M Rev) mempunyai nilai signifikan yang lebih kecil dari tingkat signifikansi $(\alpha=0,1)$, ini berarti fixed asset intensity yang dimoderasi oleh PMK 191/2015 berpengaruh signifikan dan positif terhadap Pajak Penghasilan atas Revaluasi Aktiva Tetap. Penelitian ini menemukan bahwa PMK 191/2015 melalui Surplus Revaluasi mendorong perusahaan dengan rasio aktiva tetap yang tinggi untuk ikut revaluasi. Karena oppurtunity cost yang memanfaatkan PMK 191/2015 atau tidak yang signifikan berupa penuruan tarif PPh revaluasi. Dan lagi Surplus Revaluasi yang dapat menjadi depreciable asset merupakan daya tarik bagi perusahaan yang menginginkan penghematan pajak melalui biaya penyusutan. Manfaat bagi perusahaan lainnya adalah meningkatkan ekuitas perusahaan yang bersifat non taxable bagi para pemegang sahamnya menambah daya tarik revaluasi aktiva tetap selama berlaku PMK 191/2015.

\section{Kesimpulan, keterbatasan, dan Implikasi Hasil Penelitian}

Berdasarkan hasil pengujian model struktural yang dilakukan dengan model SEM PLS menggunakan diperoleh temuan bahwa leverage tidak memiliki pengaruh signifikan terhadap $\mathrm{PPh}$ atas revaluasi aktiva tetap. Leverage memiliki hubungan negatif terhadap $\mathrm{PPh}$ atas revaluasi aktiva tetap yang artinya semakin tinggi leverage yang dimiliki perusahaan maka makin kecil $\mathrm{PPh}$ atas revaluasi aktiva tetap yang dibayarkan. Ukuran perusahaan memiliki pengaruh signifikan terhadap $\mathrm{PPh}$ atas revaluasi aktiva tetap. Ukuran perusahaan memiliki hubungan negatif terhadap $\mathrm{PPh}$ atas revaluasi aktiva tetap yang artinya semakin besar ukuran perusahaan yang dimiliki perusahaan maka makin besar PPh atas revaluasi aktiva tetap yang dibayarkan. Fixed asset intensity tidak memiliki pengaruh signifikan terhadap $\mathrm{PPh}$ atas revaluasi aktiva tetap. Fixed asset intensity memiliki hubungan positif terhadap $\mathrm{PPh}$ atas revaluasi aktiva tetap yang artinya semakin tinggi fixed asset intensity yang dimiliki perusahaan maka makin kecil PPh atas revaluasi aktiva tetap yang dibayarkan.

PMK 191/2015 melalui Surplus Revaluasi memoderasi sempurna (pure moderator) pengaruh leverage terhadap $\mathrm{PPh}$ atas revaluasi aktiva tetap. Yang artinya PMK 191/2015 mealului Surplus Revaluasi memperkuat pengaruh leverage terhadap $\mathrm{PPh}$ atas revaluasi aktiva tetap. Surplus revaluasi meningkatkan motivasi perusahaan dengan tingkat pinjaman tinggi untuk melakukan revaluasi aktiva tetap. Surplus Revaluasi berperan sebagai variabel prediktor (predictor moderasi variabel) dalam hubungan pengaruh ukuran perusahaan terhadap PPh atas revaluasi aktiva tetap. Yang artinya PMK 191/2015 mealului Surplus Revaluasi berperan sebagai variabel prediktor atau variabel bebas dalam hubungan pengaruh ukuran perusahaan terhadap PPh atas revaluasi aktiva tetap. Surplus Revaluasi memoderasi sempurna (pure moderator) pengaruh fixed asset intensity terhadap $\mathrm{PPh}$ atas revaluasi aktiva tetap. Yang artinya PMK 191/2015 mealului Surplus Revaluasi memperkuat pengaruh fixed asset itensity terhadap $\mathrm{PPh}$ atas revaluasi aktiva tetap. Surplus revaluasi yang diperoleh atas perusahaan yang melakukan revaluasi aktiva tetap meningkatkan motivasi perusahaan dengan rasio aktiva tetap yang tinggi untuk membayar PPh dan melakukan revaluasi aktiva tetap.

Keterbatasan yang ditemui peneliti adalah variabel penelitian bebas yang diteliti hanya meliputi vaiabel leverage, ukuran perusahaan, dan fixed asset intensity. Masih banyak variabel bebas lain yang dapat diuji seperti likuiditas, CFFO, kepatuhan pajak, dan variabel lainnya. 
Apabila yang diteliti dibatasi selama berlakunya periode PMK 191/2015, maka unsur variabel tarif revaluasi yang berbeda tiap periode sangat baik dimasukan untuk menambah kesempurnaan penelitian. Penelitian ini hanya mengupas gejala revaluasi seluruh sektor kegiatan usaha di Bursa Efek Indonesia. Peneltian sektor kegiatan usaha tertentu dapat dilakukan untuk lebih mendalam dan komprehensifnya penelitian. Variabel moderasi yang digunakan dalam penelitian ini adalah PMK 191/2015. Dan unsur PMK 191/2015 yang digunakan adalah variabel Surplus Revaluasi yang dihasilkan revaluasi dengan memanfaatkan PMK 191/2015. Banyak dimensi PMK 191/2015 yang dapat diuji sebagai variabel moderasi

Saran untuk penelitian selanjutnya diharapkan dapat melengkapi keterbatasan yang ada dalam penelitian ini dengan mengembangkan sampel dan variabel sehingga memberikan bukti empiris mengenai $\mathrm{PPh}$ atas revaluasi aktiva tetap dan faktor-faktor yang mempengaruhinya. Saran untuk stake holder dan pengguna laporan keuangan diharapkan penelitian ini memberikan informasi yang relevan serta handal dalam pengambilan keputusan. Saran untuk perusahaan anggota Bursa Efek Indonesia diharapkan penelitian ini menjadi masukan bagi manajemen dalam mengambil keputusan revaluasi aktiva tetap. Saran bagi pemerintah dalam membuat regulasi diharapkan penelitian dapat memberikan kontribusi terciptanya regulasi yang efektif bagi penerimaan pajak dan memberikan insentif yang tepat sasaran bagi pertumbuhan ekonomi serta iklim yang baik bagi dunia usaha .

\section{Daftar Referensi}

Agnes Cheng, C. S., \& Lin, S. W. (2009). When do firms revalue their assets upwards? Evidence from the UK. International Journal of Accounting \& Information Management, 17(2), 166-188.

Chrisdianto, R. B., \& Katik, Y. Y. B. (2011). Evaluasi Perencanaan Pajak Melalui Revaluasi Aset tetap Untuk Meminimalkan beban Pajak Perusahaan (Studi Kasus pada PT." X").

Cotter, J., \& Richardson, S. (2002). Reliability of asset revaluations: The impact of appraiser independence. Review of Accounting Studies, 7(4), 435-457.

Dewi, P. N. (2014). Implementasi Revaluasi Aset Tetap Berdasarkan Peraturan Menteri Keuangan No. 79 Tahun 2008 Pada Perusahaan Di Indonesia. Jurnal Akuntansi UNESA, 2(2).

Downs, T. W., \& Demirgures, C. (1992). The asset price theory of shareholder revaluations: Tests with the tax reforms of the 1980s. Financial Review, 27(2), 151184.

Emmanuel Iatridis, G., \& Kilirgiotis, G. (2012). Incentives for fixed asset revaluations: the UK evidence. Journal of applied accounting research, 13(1), 5-20.

FASB, (1987),"Element of Financial Statement of Business Enterprises", SFAC No.3, Hendriksen, Eldon S and Michael F Van Breda, 2000 Accounting Theory5th Edition. Prentice Hall

Fauziati, P., Minovia, A. F., \& Khairati, A. (2015). Pengaruh Leverage, Arus Kas Operasi, Ukuran Perusahaan dan Fixed Asset Intensity Terhadap Revaluasi Aset Tetap.

Georgescu, I., Păvăloaia, L., \& Robu, I. B. (2014). Fair value accounting and market reaction: evidence from Romanian listed companies. Procedia-Social and Behavioral Sciences, 143, 827-831.

Hanlon, D., Navissi, F., \& Soepriyanto, G. (2014). The value relevance of deferred tax attributed to asset revaluations. Journal of Contemporary Accounting \& Economics, 10(2), 87-99.

Hikmah, N. (2016). Implikasi Penerapan PMK 191/PMK. 010/2015 Terhadap Pelaksanaan Revaluasi Aktiva Tetap (Studi Kasus Pada PT Pembangkitan Jawa Bali). Jurnal Ilmiah Mahasiswa FEB, 4(2). 
Kurniawati, H. (2013). Analisis dan Tren Penggunaan Accounting Choice yang dilakukan Perusahaan di Indonesia Pasca Adopsi IFRS. Binus Business Review, 4(2), 765-775.

Latifa, C. A., \& Haridhi, M. (2016). Pengaruh Negosiasi Debt Contracts, Political Cost, Fixed Asset Intensity, dan Market To Book Ratio terhadap Perusahaan Melakukan RevaluasiAset Tetap (Studi pada Perusahaan Manufaktur yang Terdaftar di Bursa Efek Indonesia Tahun 2010-2014). Jurnal Ilmiah Mahasiswa Ekonomi Akuntansi, 1(2), 166176.

Saptono, Prianto Budi, and Eko Suwardi. "IFRS Convergence and Its Impacts on Taxation: A Case Study on Fixed Assets in Indonesia." Proceedings of 23rd International Business Research Conference. 2013.
Schwarz, Zdeněk, Jana Buchtova, and Petra Beranova. "The Issues Relating to Repoering and Valuation Of Long-Term Tangible Fixed Asset in Accounting of Industrial Enterprise."

Tabari, Naser Yadollahzadeh, and Marzieh Adi. "Factors Affecting the Decision to Revaluation of Assets in Listed Companies of Tehran Stock Exchange (TSE)." International Journal of Scientific Management and Development 2.8 (2014).

Tay, Ink. Fixed asset revaluation: management incentives and market reactions. Diss. Lincoln University, 2009.

Zakaria, A., Edwards, D. J., Holt, G. D., \& Ramachandran, V. (2014). A Review of Property, Plant and Equipment Asset Revaluation Decision Making in Indonesia. Mindanao Journal of Science and Technology, 12. 